\title{
THE EFFECT OF COMPENSATION AND LEADERSHIP STYLE TOWARDS EMPLOYEES PERFORMANCE
}

\author{
Dyka Febriana Fitrianingrum \\ Management Department, Faculty of Economics and Business \\ Universitas Muhammadiyah Malang \\ E-mail: dykafebriana31@gmail.com
}

\begin{abstract}
This study aims to describe the compensation, leadership style, and the performance of employees and also to know the influence of compensation and leadership style partially and simultaneously to the performance of employees of PT. Hartria Akas Green Sejahtera. The respondents of this research were all employees of drivers and conductors of Patas Bus consisting of 75 people. The sampling technique used was census method. In analyzing the data, the researcher used multiple scale and linier regression. The hypothesis testing used $t$-test and $F$-test. The result of scale range analysis showed that the performance of the employees is high, the compensation is good, and the leadership style applied by company is achievement oriented. In addition, the results of multiple linier regression analysis portrayed that the compensation and leadership style influence significantly, partially and simultaneously to the performance of employees of PT. Hartria Akas Green Sejahtera.
\end{abstract}

Keywords: compensation, employee performance, leadership style

\section{INTRODUCTION}

Business requires employees' high performance in order to strive. Therefore, companies always have to attempt to increase and improve their worker's performance. Business competitions put pressure for companies to strive by providing the best service to their consumers. Companies' successes are influenced by several factors, one of which is the human resource who man all of the organizations' hierarchy, from the planning to the evaluation process, and who make use of other resources and assets of the companies.

Human resource plays an important role in any company as they are the ones who run the organization. Human resource potential has to be maximized in order to produce optimal output. Reliable, highly responsible and hardworking employees are necessary resources for every company. Competent and good performing human resource can sustain and develop the business. On the other hand, incompetent human resource and bad performance put companies at losing situation in the business competition. To ensure any company's good performance, the management ought to consider several aspects such as compensation and leadership style. This will allow management to create human 
resource as one of the important indicators to reach the organization's goals effectively and efficiently.

\section{LITERATURE REVIEW}

In any organization, the employees' work performance determines the success of the goal accomplishment. An employee performance has to be seen individually as each of them has different capability to do their tasks. Companies can increase their employees' performance by nurturing them so as to maximize their sense of responsibility to do their work.

Harbani Pasolong (2010)
explains several factors that
influence employees, performance are ability, willingness, energy, technology, compensation, clarity of goals, and security. Proper compensation is employees rights and the company's responsibility in order to support employees' contribution to reach organization's goals. To ensure the company goal attainment, the company can show support by providing compensation as it can be considered as reciprocal relationship between organization and its human resource. In addition, other factors influencing employee performance are personal or individual, leadership, team, system and contextual factors (Mahmudi, 2010).

Employee's good performance can be enhanced by modelling good performance by the companies' board of leaders that is leaders who can motivate and take notice of their works. Leadership is a process of providing influence and modelling by the leaders towards the subordinates in order to achieve the organization goals. Leadership focuses on the leaders and the process or methods that they do to clarify the company's goals for the employees or their subordinates, to motivate them to achieve those goals, and to support them to create productive culture in the organization.

From the previous explanation, it can be concluded that compensation and leadership are important factors directly influencing employee performance. The current research project focuses on the transportation company PT Hartia Akas Green Sejahtera. The respondents of the current project are all of the employees involved in Patas service consisting of 75 drivers and driver assistants. All of those employees are partner employees.

Mangkunegara (2009) explains the word job performance or actual performance as the quality and quantity of work done by employees in conducting the tasks assigned to them. According to the interview with the leader of PT Hatria Akas Green Sejahtera, the efforts to create good work performance in the company still need optimizing which is evidenced by the high number of consumer complaints received by the company. Table 1 presents the customer complaints received from January to June 2017. 
Table 1. Customer Complaints Received January - June 2017

\begin{tabular}{|c|c|c|c|c|}
\hline \multirow[b]{2}{*}{ Month } & \multirow[b]{2}{*}{ Qty } & \multicolumn{3}{|c|}{ Customer Complaints } \\
\hline & & $\begin{array}{c}\text { No change } \\
\text { given }\end{array}$ & $\begin{array}{c}\text { Reckless } \\
\text { Driving }\end{array}$ & Left goods \\
\hline Jan & 50 & 61 & 24 & 20 \\
\hline Feb & 41 & 80 & 20 & 20 \\
\hline Mar & 59 & 70 & 15 & 12 \\
\hline Apr & 33 & 69 & 11 & 24 \\
\hline May & 39 & 81 & 9 & 22 \\
\hline June & 48 & 63 & 11 & 18 \\
\hline
\end{tabular}

Table 1 shows some customer complaints received by the company. Customers file their complaints by call where they explain their complaints directly about the unpleasant experience when using the company service. When making complaints, the customer is asked to provide their ticket serial number so the company can track the route and the crew involved in the complaint.
In June, the total number of the complaints fluctuated. Many customers reported unpleasant experience when using this transportation service. Those complaints were received due to the rule violation by the company employees. Basically, the crew had understood their rights and responsibilities, and violations of the rules are considered unacceptable.

Table 2. Employee Rule Violation. January - June 2017

\begin{tabular}{lcccccc}
\hline Month & Qty & $\begin{array}{c}\text { No change } \\
\text { given }\end{array}$ & $\begin{array}{c}\text { Reckless } \\
\text { driving }\end{array}$ & Left goods & Accident & $\begin{array}{c}\text { Receiving } \\
\text { Ticket }\end{array}$ \\
\hline Jan & 50 & 61 & 24 & 20 & 4 & 33 \\
Feb & 41 & 80 & 20 & 20 & 1 & 25 \\
Mar & 59 & 70 & 15 & 12 & 3 & 30 \\
Apr & 33 & 69 & 11 & 24 & 2 & 11 \\
May & 39 & 81 & 9 & 22 & 2 & 19 \\
Jun & 48 & 63 & 11 & 18 & 1 & 24 \\
\hline
\end{tabular}

Table 2 shows the fluctuation in rule violation done by the company's employees in January June 2017. The current project employs Schuller and Jackson's (1992) framework to assess employee performance, which is based on the work quantity, work quality, punctuality, cooperation and attitude. When control was enforced and a crew was known not to give tickets to certain passengers, this rule violation fell into the indicators of work quality, cooperation and attitude. Work quality includes the service performed by the crew towards the passengers. As indicated in Table 1, there were high numbers of customer complaints which proved that the work quality of PT Hartria Akas Green Sejahtera employees was not good enough.

For the indicators of cooperation and attitude, the crew (drivers and driver assistants) were responsible to work in team and not individually as the tasks and activities in the organization are 
closely related to each other. In other words, without team work, the organization activities are not going to be effective. The crew work together to do their work, thus any decision made during the drive, both the driver and the driver assistant are accountable for it, including when rule violation was made, such as no change was given to customer.

In addition, another indicator of attitude which shows employee's positive performance is their ability to do their tasks without the company's direct supervision. Some employees were considered of lesser attitude due to the relatively high frequency of rule violation, such as not giving tickets to passengers. If such cases are discovered, they will be sanctioned accordingly.

Other than the rule violations described in Table 2, many employees also could not reach the monthly passenger target. This aspect is one of the indicators of good work performance in addition to the work quality and punctuality. The company set the monthly target of getting 2200 passengers in 25 days of work in a month. PT Hatria Akas Green Sejahtera has five bus routes, each with return trip each day. The total number of the seats in each bus is 44 for Patas buses, so it can take maximum 44 buses in each ride. From the target of 2200 passengers, in average the crew could get only $50 \%$ of it. If a crew could not reach the target continuously in certain time frame, they will be formally investigated as to why they could not meet the target. This usually becomes a push for them to work harder and meet the target.
Compensation is a form of award given to the deserving employee, which can be financial or non-financial. Simamora (2004) suggests that there are four types of compensation indicators; they are salary, incentives, allowance, and facilities. The compensation system used in PT Hatria Akas Green Sejahtera is the result system, which amount was determined by the result of employee work performance, in this case the total passengers they get in a month. The crew is partner employees who receive extra $30 \%$ from their nett income, as regulated in the compensation indicator in the form of salary.

The proportion $30 \%$ compensation was further divided into $17 \%$ of extra income and $13 \%$ bonus (premium). The extra income can be withdrawn daily, while the bonus can be withdrawn every 10 days or once a year. They are still further divided between the number of crew, generally consisting of two people with different tasks, the driver and the driver assistant. The 17\% extra income is divided into $10 \%$ for the driver and $7 \%$ for the driver assistant. As for the 13\% bonus, $7 \%$ is given to the driver, and the rest is for the assistant.

For the employees, the percentage of income with a profit sharing like this one still cannot help them meet their daily needs, especially during non-peak hours/ days. One of the reasons the crew conduct rule violation is because of this, thus making them earning less. As a result, many employees cannot meet the monthly target of 2200 passengers within 25 working days, 
and thus not receiving any bonus. Bonus in the form of incentive is one of the compensation indicators. In this case, the employees will receive the bonus when they meet the target set by the company.

In addition, the crew's status as partner employee entitles them only to one special holiday (hari raya) allowance. They even pay their health insurance $(B P J S)$ personally; the company only assists them in organizing it. The company owns special fund in case of accident (Sumber Dana Kecelakaan--SDK) which originates from the crew's income deducted in every trip. The deduction is $\mathrm{Rp} 3,000$,- per day for the driver, and $\mathrm{Rp} 1,500$,- per day for the driver assistant.

According to Robin and Judge (2015), leadership is the ability to influence a group of people to work together to reach certain goal. Leader has a big influence towards employee performance. Leader of a company should provide good example for the employee so they can do their work better. The current project uses theory of path-goal leadership style. According to House in Robbins and Coulter (2010), there are four behaviors in the theory of path-goal; directing leader, supporting leader, participating leader, and achievement-oriented leader.

Interview results with some employees show that the leader of PT Hatria Akas Green Sejahtera likes to blend with them, thus placing himself as a colleague. This is in line with the supporting style leadership. In addition, they reported that the leader was always bold and explains their tasks and targets, which is in line with the directing leadership style. On the other hand, the leader loves employee who shows good work performance, which is in line with the achievement-oriented leadership style. There are previous research about the influence of compensation and leadership style towards employee work performance. Mujiati and Setiawan (2016), Hamdiyah et al (2016) and Hatta et al (2017) show that compensation significantly improve employee work performance. On the other hand, Pradita (2017) claims that compensation significantly and negatively impact on employee work performance. Together, Mujiati and Setiawan (2016), Hamdiyah et al (2016) and Pradita (2017) found that leadership style significantly affect employee work performance, but Hatta (2017) found that leadership style does not significantly affect employee performance. The current project describes employee performance, compensation, and leadership style. In addition, this research also aims to find out the influence of compensation and leadership style, both partially or continuously, towards the employees of PT Hatria Akas Green Sejahtera. So this study framework will be seen as in Figure 1.

\section{METHOD}

The current project employed survey method. The population covered all the partner employees responsible for patas buses, with the total number of 75 employees. The sample was taken using the census method. The variables in this studi is compensation, leadership style, and employee work performance. 
Employee performance was measured using the quantity of work, punctuality, cooperation and attitude. Compensation was measured using the salary, incentive, allowance and facilities. Leadership style was measured using four leadership behaviors; directing leader, supporting leader, participating leader and achievement -oriented leader. The current project employed primary data originating from interview and questionnaire. Likert scale was used to measure variables. The data obtained were then analyzed using scale-range in order to describe each variable, while double linier regression was employed in order to discover the relationships of each variable. The hypothesis of this research was tested using t-test to discover the partial influence, and F-test to discover the simultaneous influence.

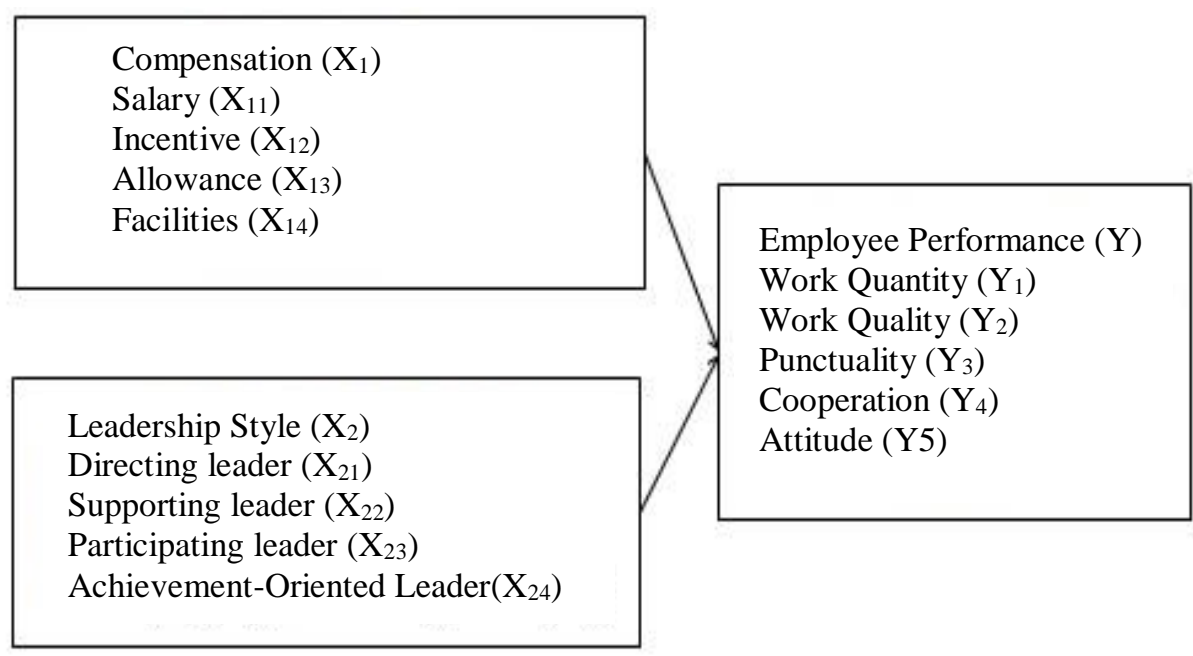

Figure 1. Research Concept Framework

\section{RESULT AND DISCUSSIONS}

The measurement and the study range were conducted by doing analysis and interpretation towards the frequency distribution, including variation of responses from each respondent in answering questions from the questionnaires. Table 3 shows the variable scale range of the employees' performance based on the distribution of respondents' responses:

Table 3. The Analysis Result of Scale Range Variable of the Employees' Performance

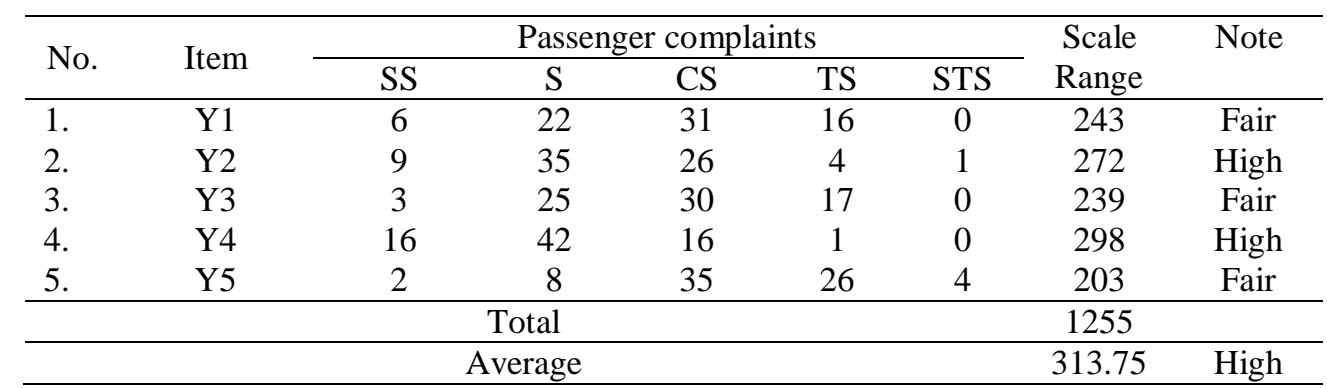


Table 3 shows that the average of scale range variable of the employees' performance is 313.75 . The score is considerably high, which indicates that the employees' performance is also high based on a number of indicators such as work quantity, work quality, punctuality, cooperation, and attitude. On Table 3 , the fifth statement (Y5) in fact gained the lowest score. Y5 discussed about employees' attitude at work based on their job description without being supervised by the company's representatives, unfortunately, a few employees conducted some rule violation, for instance, giving no change for passengers or receiving violation tickets. This attitude indicates that some employees still cannot work properly without any supervision from the company. On the contrary, the fourth statement (Y4) gained the highest score of 298 in terms of cooperation. It means there is a good cooperation among the employees in doing their jobs, especially since a bus is becoming the responsibility of all crews, including the drivers and driver assistants. Next, the following table describes the variable scale range of compensation based on the respondents' responses:

Table 4. The Analysis Result of Variable Scale Range of Compensation

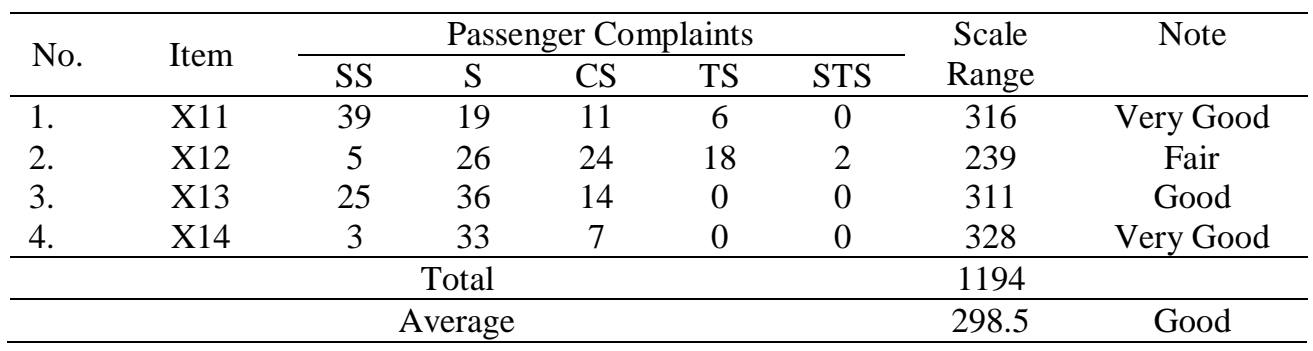

According to Table 4, the average of variable scale range of compensation is 298.5. This score is relatively good, which implies that the compensation given by PT. Hartria Akas Green Sejahtera to its employees is good based on a number of indicators such as salary, incentives, allowances, and facilities. From the four indicators, the fourth statement (X14) relating to facilities received the highest score of 328 which means very good. Most employees agreed if the facilities provided by PT. Hartria Akas Green Sejahtera have met the basic needs of the employees, such as parking area, praying room, rest area, toilet, and health center.

Another good score was found for the first question (X11) which dealt with employees' salary. The employees are often awarded with proper salary in accordance with the number of passengers they could obtain. It shows that PT. Hartria Akas Green Sejahtera has paid their employees well, not only in terms of financial compensation but also nonfinancial compensation such as facilities that the employees need. Moreover, the following table shows the variable scale range of leadership based on the respondents' responses: 
Table 5. The Analysis Result of Variable Scale Range of Leadership

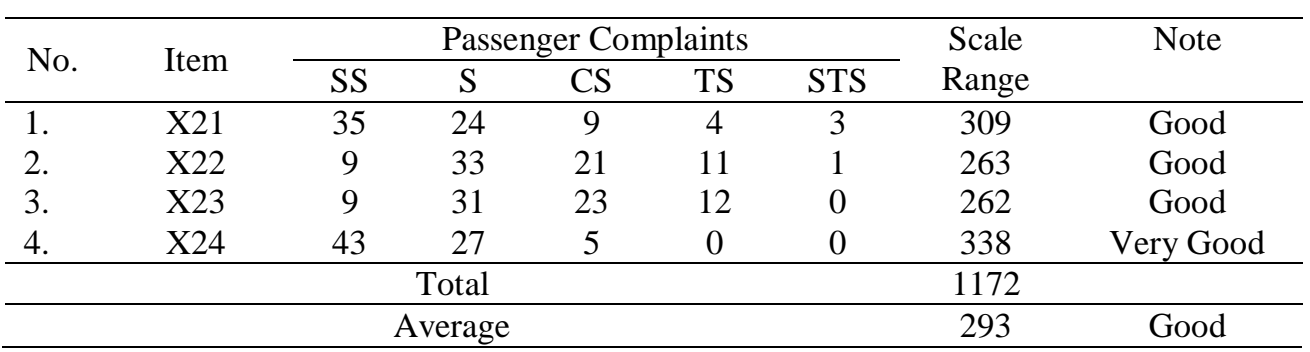

Table 5 shows that the average score of variable scale range of leadership is 293 which points out that the leaderships at PT. Hartria Akas Green Sejahtera is relatively good due to a number of indicators. The fourth statement (X24) gained the highest score of 338 which is very good. The board of leaders of PT. Hartria Akas Green Sejahtera applies a leadership system which focuses towards achievement, thus they stimulate their employees to reach the target (2200 passengers within 25 days) by giving bonus (in the form of fresh money) once they reach the target. Besides, the boards are also clear in directing their employees to do their job descriptions and reach the targets that they should achieve. Multiple linear regression analysis was employed to analyze the effect of compensation and leadership variables towards employees' performance variable. The analysis was conducted after the result of questionnaire responses have passed a number of tests, including validity, reliability, and multiple linear regression analysis:

Table 6. The Result of Multiple Linear Regression Analysis

\begin{tabular}{lcccc}
\hline \multicolumn{1}{c}{ Variable } & $\begin{array}{l}\text { Regreesion } \\
\text { Coefficient }\end{array}$ & T count & Sig. t & \\
\hline Constant & 2.500 & & & \\
Compensation $(\mathrm{X})$ & 0.544 & 4.531 & 0.000 & \\
Leadership Style (X2) & 0.357 & 3.026 & 0.003 & \\
\hline $\mathrm{R} \quad=0.782$ & Adj. $\mathrm{R}^{2}=0.601$ & & \\
$\mathrm{R}^{2} \quad=0.612$ & F-count $=56.702$ & Sig. F & $=0.000$ \\
\hline
\end{tabular}

Based on Table 6, the regression equation is as follows:

$$
\begin{gathered}
Y=a+b_{1} X_{1}+b_{2} X_{2}+e \\
Y=2,500+0,544 X_{1}+0,357 X_{2}+e
\end{gathered}
$$

From the equation, it is known that the employees' performance (Y) score was predicted by compensation (X1) and leadership (X2) variables at PT. Hartria Akas Green Sejahtera. It was also discovered that the estimated value of employees' performance at PT. Hartria Akas Green Sejahtera is 2.500 which means if compensation and leadership are not available; the value of $\mathrm{Y}$ is 2.500 .

The compensation variable (X1) of 0.544 indicates that there is a positive impact from compensation towards employees' performance. 
When the compensation is increased, the employees' performance will also increase with the assumption that there is no other existing variable or zero variable. In that case, the better the compensation given to the employees, the higher their performance would be.

The leadership variable of 0.357 also indicates positive correlation between leadership styles towards employees' performance. When the leadership improves, the employees' performance will also increase with assumption there is no other existing variable or zero variable. Thus, the better the leadership style applied, the higher the employees' performance would be.

Referring to Table 6, it is known that the value of $\mathrm{R}^{2}$ is 0.612 which implies that compensation variable distribution (X1) and leadership variable (X2) define employees' performance variable (Y)

\section{REFERENCES}

Arikunto, Suharsimi. 2006. Prosedur penelitian: Suatu pendekatan praktis. Edisi Revisi VI. Jakarta: Rineka Cipta

Ghozali, Imam. 2016. Aplikasi analisis multivariate dengan program SPSS 21. Semarang: UNDIP.

Hamdiyah, dkk. 2016. Peningkatan Kinerja Karyawan Melalui Kompensasi, Lingkungan Kerja, dan Gaya Kepemimpinan di ADA Swalayan Banyumanik Semarang. Journal of Management. Vol.02, No.02. for $61.2 \%$, while the rest of $38.8 \%$ is defined by other variables. Based on Table 6, the F-count value is 56.702 with significance level of 0.000 which is bigger than F-table of 3.12, thus the third hypothesis in this study is accepted and it can be concluded that compensation and leadership style simultaneously have significant effect towards employees' performance at PT. Hartria Akas Green Sejahtera.

\section{CONCLUSION}

Based on the data of t-test on Table 6 , compensation variable (X1) has t-count of 4.531 with significance level of 0.000 , while the leadership variable (X2) t-count value is 3.026 with significance level of 0.003 . In conclusion, the first and second hypotheses are accepted and it implies that compensation and leadership partially affect the employees' performance at PT. Hartria Akas Green Sejahtera.

Hasibuan, M, SP. 2002. Manajemen Sumber Daya Manusia, Edisi Revisi, Jakarta: Bumi Aksara.

Hatta, dkk. 2017. Pengaruh Gaya Kepemimpinan, Kerjasama Tim, Dan Kompensasi Terhadap Kepuasan Kerja Serta Dampaknya Pada Kinerja Karyawan PT. PLN (Persero) Wilayah Aceh. Jurnal Magister Manajemen, Fakultas Ekonomi dan Bisnis Unsyiah. Vol.1, No.1, hlm: 70-80.

Johannes, dkk. 2016. Pengaruh Gaya Kepemimpinan, Kompensasi, Dan Lingkungan Kerja Terhadap Kinerja Agen pada AJB Bumiputera 1912 Cabang 
Tikala. Jurnal Berkala Ilmiah Efisiensi. Vol.16, No.01.

Kartono, Kartini. 2008. Pemimpin dan kepemimpinan. Jakarta: Raja Grafindo Persada.

Mahmudi. 2010. Manajemen kinerja sektor publik. Yogyakarta: STIM YKPN.

Mangkunegara, A.A. Anwar Prabu. 2009. Manajemen Sumber Daya Manusia. Bandung: Remaja Rosdakarya.

Martoyo. 2007. Manajemen Sumber Daya Manusia edisi kelima. Yogyakarta: BPFE.

Nawawi, Hadari. 2013. Kepemimpinan Mengefektifkan Organisasi. Yogyakarta: Gadjah Mada University Press.

Pasolong, Harbani. 2010. Teori Administrasi Publik. Bandung: Alfabeta.

Pradita. 2017. Pengaruh Kompensasi, Gaya Kepemimpinan, dan Karakteristik Tenaga Pemasar Terhadap Motivasi dan Kinerja Tenaga Pemasar Pada PT. Bank Rakyat Indonesia (Persero) Tbk. Cabang Jombang. Jurnal Bisnis dan Manajemen ISSN 1829-7528. Vol.4, No.2, hlm: 153-164.

Rivai, Veithzal. 2004. Manajemen sumber daya manusia untuk perusahaan: Teori ke Praktik. Jakarta: Raja Grafindo Persada.

Robbins, Stephen P \& Judge, Timothy A. 2015. Perilaku organisasi edisi 16. Jakarta: Salemba Empat.

Robbins, Stephen P \& Coulter, Mary. 2010. Manajemen, edisi kesepuluh jilid 2. Jakarta: Erlangga.

Santoso, Singgih. 2012. Panduan variabel-variabel penelitian. Bandung: Alex Media Komputindo.

Setiawan \& Mujiati. 2016. Pengaruh Gaya Kepemimpinan Dan Kompensasi Terhadap Kinerja Karyawan PT. Astra Honda Nusa Dua Kabupaten Badung. E-Jurnal Manajemen Unud. Vol.5, No.12, hlm: 7956-7983.

Schuller S. Randal, Jackson E, Siusan. 1992. Manajemen Sumber Daya Manusia Menghadapi Abad-21 Edisi Keenam (terjamahan). Jakarta: Erlangga.

Simamora, Henry. 2004. Manajemen sumber daya manusia edisi ketiga. Yogyakarta: STIE YKPN.

Sugiyono. 2004. Metode penelitian bisnis. Bandung: Alfabeta..

Sugiyono. 2012. Metode penelitian bisnis (pendekatan kuantitatif, kualitatif, dan $R \& D)$. Bandung: Alfabeta.

Sutikno, Sobry. 2014. Pemimpin dan kepemimpinan: Tips Praktis untuk Menjadi Pemimpin yang Diidolakan. Lombok: Holistica.

Thoha, Miftah. 1993. Kepemimpinan dalam manajemen Ed. 1, Cet. 5. Jakarta: Raja Grafindo Persada.

Umar, Husein. 2001. Riset sumber daya manusia dalam organisasi. Jakarta: Gramedia Pustaka Umum.

Wibowo. 2007. Manajemen kinerja. Jakarta: Raja Grafindo Persada.

Wirawan. 2009. Evaluasi kinerja sumber daya manusia: teori aplikasi dan penelitian. Jakarta. Salemba Empat 